\title{
SPATIAL AND TEMPORAL FEATURES OF THE TIMIŞ RIVER (BANAT, ROMANIA) LIQUID FLOW REGIME
}

Marioara COSTEA *

* "Lucian Blaga" University of Sibiu, Faculty of Sciences, Department of Ecology and Environment Protection, Dr. Ioan Raţiu Street 5-7, Sibiu, Sibiu County, Romania, RO-550012, marioara_costea@yahoo.com

DOI: $10.2478 /$ trser-2013-0028

KEYWORDS: hydrological regime, maximum and minimum flow, Timiş River.

\section{ABSTRACT}

This paper presents an analysis of the flow regime of the Timiş River in Romania. The analysis was based on hydrological data provided by the National Institute of Hydrology and Water Management in specialized publications (hydrological yearbooks or online series). The data were supplemented by personal observations in the field. The following leakage parameters were analyzed: average flow (monthly, seasonal, annual), maximum flow (especially flash floods) and minimum leakage. This paper highlights the link between hydrological parameters and conditioning factors of spatial distribution (characteristics of the geological substratum, relief units, elevation, slope) and temporal variation of flow (in function of type of supply, and variability and variation of climatic conditions).

ZUSAMMENFASSUNG: Räumliche und zeitgebundene Eigenschaften im Abflussregime des Timiş-Flusses (Banat, Rumänien).

Vorliegender Beitrag umfasst eine Analyse des Abflussregimes des Flusses Timiş in Rumänien. Sie beruht auf hydrologischen Daten aus Fachveröffentlichungen des Nationalen Instituts für Hydrologie und Wasserwirtschaft (hydrologische Jahrbücher oder Online Reihe). Die Daten wurden durch eigene Beobachtungen im Gelände ergänzt. Als Parameter für das Abflussregime wurden der mittlere Durchfluss (monatlich, saisonal, jährlich), die maximale Durchflussmenge (insbesondere Überschwemmungen) und minimaler Durchfluss. Der Beitrag hebt die Verbindung zwischen hydrologischen Parametern und den Faktoren hervor, die räumliche Verteilung (Merkmale des geologischen Untergrunds, Reliefeinheit Entlastungseinheit, Höhe, Gefälle) sowie die zeitlichen Schwankungen im Abflussregime bedingen.

REZUMAT: Caracteristici spaţiale şi temporale ale scurgerii lichide pe râul Timiş (Banat, România).

Lucrarea prezintă o analiză a regimului de scurgere a râului Timiş pe teritoriul României. Analiza s-a realizat pe baza datelor hidrologice, furnizate de Institutul Naţional de Hidrologie şi Gospodărire a Apelor, prin publicaţii de specialitate (anuare hidrologice sau serii online). Datele au fost completate de observaţiile proprii din teren. Au fost analizaţi parametrii scurgerii lichide: scurgerea medie (lunară, sezonieră, anuală), scurgerea maximă şi scurgerea minimă. Lucrarea evidenţiază legătura dintre parametri hidrologici şi factorii care condiţionează repartiţia spaţială (caracteristicile substratului geologic, unitatea de relief, altitudinea, panta) şi variaţia temporală a scurgerii (tipul de alimentare, variabilitatea şi variaţia condiţiilor climatice). 


\section{INTRODUCTION}

Timiş is the main river of the south-western part of Romania. The river has its origin on the eastern slope of Semenic Mountains, at an altitude of 1,135 m below the Piatra Goznei Peak $(1,145 \mathrm{~m})$. Timiş course exceeds the state border of Romania and flows into the Danube at Pančevo in Serbia, downstream from Belgrade. The total length of the river course is about $359 \mathrm{~km}$, of which $241.2 \mathrm{~km}$ is in Romania (from spring and to the country border, at Grăniceri).

The Timiş River basin is a part of the Danube River basin and drains an area of 7319 $\mathrm{km}^{2}$, of which $5795 \mathrm{~km}^{2}$ is on the national territory (NIMH, 1971), as part of the Banat basin (Fig. 1), and is a large complex basin; its catchment area overlapping on distinct relief units: mountains, hills, plains.

The upper basin of the Timiş represents about $20 \%$ of the reception surfaces in Romania and includes the following mountain units: the eastern part of the Banat Mountains (to the left side of Timiş River), the western part of Ţarcu - Muntele Mic and Poiana Ruscă mountains (to the right side) and Timiş-Cerna corridor (along the river, including the Caransebeş Depression - an intra-Carpathian depression) (Oancea and Velcea, 1987).

Almost all mountain tributaries in this sector are short, with a strong torrential flow regime imposed by slope and supply regime. The declivity and the permanent flow on Timiş and on the main tributaries (Sebeş) confer to this sector's hydropower potential. In the north extremity of the upper basin, in the Caransebeş Depression, the significant decrease of declivity has generated changes of the river courses and a current active dynamic through meandering.

The middle basin of Timiş comprises of relief units with lower altitudes: Lugojului Hills to north-east of the city of Lugoj, the Pogănişului Hills to the south of this city, Lugoj Plain between the confluence with Bistra and Timişana rivers and Timiş Plain from Hitiaş due west to the state border of Romania (Badea and Bugă, 1992). From a morpho-hydrographic point of view this sector presents the following characteristics: active subsidence, meandering and stationary hydrodynamic processes due to the very low declivity.

The extreme Timiş lower basin is developed on the Serbian Banat territory. In morphohydrographic terms it retains the same characteristics similar to the middle sector. The river is arranged, channelled, and is part of the Danube - Timiş - Danube hydro graphic system.

The Timiş Basin shape is elongated from east to west, with an obvious asymmetry in the upper and middle sectors, due to the differences in the length of its tributaries. Thus, in the upper basin, it has an oval shape. The river has a general flowing direction from south to north, longer tributaries on the right part (Pârâul Rece, Sebeş, Bistra) and shorter tributaries on the left part. In the middle sector, the Timiş River has a general flow direction from east to west, and the basin has a trapezoidal shape with the basis to the north and an obvious left asymmetry due to numerous and longer tributaries (Pogăniş, Lanca-Barda, Barzava and Moraviţa) (Fig. 1).

From the entire basin surface developed in Romania, the right side occupies $47 \%$, with an area of $2745 \mathrm{~km}^{2}$ and the left side is of $53 \%$, with an area of $3050 \mathrm{~km}^{2}$. Morphometric elements of the Timiş River basin are cumulated in table 1. 


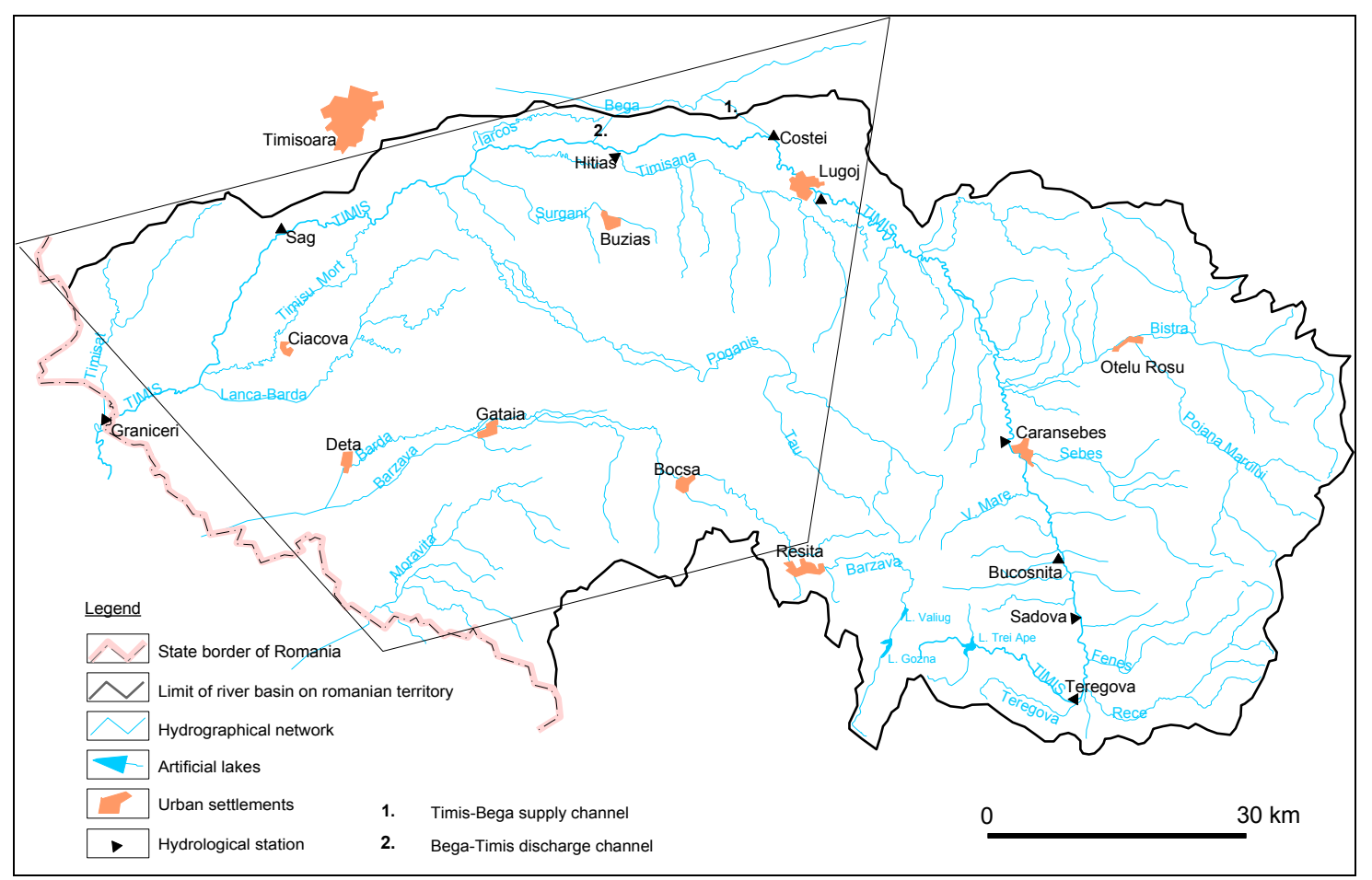

Figure 1: Hydrographic system of the Timiş River and its shape on sectors.

Table 1: Morphometric parameters of the Timiş River basin; Source: Ujvari I., 1972, verified in INMH sources and analytical on a topographic map, scale 1:25000; Hm - mean basin elevation, Im - mean basin slope, F - basin surface, H - section elevation, L - course length from sources to the hydrological station.

\begin{tabular}{|c|c|c|c|c|c|c|}
\hline \multirow[b]{2}{*}{ River } & \multirow[b]{2}{*}{ Section } & \multirow[b]{2}{*}{$\mathrm{L}(\mathrm{km})$} & \multirow[b]{2}{*}{$\mathrm{H}(\mathrm{m})$} & \multicolumn{3}{|c|}{ River basin } \\
\hline & & & & $\mathrm{F}\left(\mathrm{km}^{2}\right)$ & $\mathrm{H} \mathrm{m} \mathrm{(m)}$ & $\begin{array}{c}\mathrm{I} \\
\mathrm{m}(\mathrm{m} / \mathrm{km})\end{array}$ \\
\hline \multirow{10}{*}{ Timiş } & source & 0 & 1135 & - & - & - \\
\hline & Sadova & 36.8 & 295 & 559 & 933 & 309 \\
\hline & Petroşniţa & 47.7 & 245 & 740 & 847 & 293 \\
\hline & Caransebeş & 60.0 & 200 & 1072 & 769 & 286 \\
\hline & $\begin{array}{l}\text { Confluence with } \\
\text { Bistra River }\end{array}$ & 71.7 & 184 & 2032 & 782 & 299 \\
\hline & Lugoj & 116.4 & 117 & 2706 & 665 & 258 \\
\hline & $\begin{array}{l}\text { Confluence with } \\
\text { Cheveres River }\end{array}$ & 169.5 & 96 & 3614 & 533 & 201 \\
\hline & $\begin{array}{l}\text { Confluence with } \\
\text { Pogăniș River }\end{array}$ & 174.0 & 95 & 4413 & 475 & 178 \\
\hline & Şag & 194.1 & 82 & 4493 & 468 & 175 \\
\hline & at the border & 241.2 & 72 & 5795 & 415 & 151 \\
\hline
\end{tabular}




\section{METHODS}

The study was based on literary research, research in the field, collection, and mapping and interpreting of data and information provided by maps, and specialized institutions or locals. The characterization of the hydrological regime in the Timiş River basin was aimed to highlight the average, minimum and maximum flow. The hydrological analysis was based on data collected from the hydrological yearbooks and from the river's hydrological monograph developed by NIMH (1971). Data was updated based on personal field observations, online data from INHGA and recent works (Linc, 2002; Pantu, 2009). The liquid flow analysis was extended to the entire river basin through the correlation between the specific flow and mean elevation of the basin. We analyzed the specific average flow and its seasonal distribution. The hydrological risk phenomena were reported by analyzing maximum and minimum leakage.

\section{RESULTS AND DISCUSSION}

\section{Liquid flow regime}

Knowing the flow regime of the rivers, and implicitly of the Timiş River, is particularly important for sustainable management of water resources and for ensuring an ecological balance in minor riverbeds and floodplains of collector and tributaries, mostly in the conditions in which the human intervention in the Timiş Basin has been significant since historical times.

\section{The average liquid flow}

Average flow is directly influenced by the morphometric characteristics of the river basin (developing in altitude and surface, shape, slope), climatic elements (by rainfall, temperature, evaporation) and by the use of land etc. The Timiş River and its representative tributaries have a permanent drainage system, but first order courses from mountainous region and the I, II and III order courses of the hills and the plains have a temporary drainage system imposed by periodic variation of the non-periodic variability of rainfall (note that the river's order is established according to Horton-Strahler hierarchy).

In these conditions, the Timiş River reaches the hydrological parameters shown in table 3. It should be noted that the leakage regime is controlled by the hydro power stations systems on Timiş River or on its tributaries in mountainous areas, (accumulation of Trei Ape supplements by pumping on pressure pipes the water flow in the Bârzava Basin) (Pop, 1996) or the Pogăniş Hilly region (Badea and Bugă, 1992). The lateral arrangements from the Timiş Plain are also designed to regulate and reduce the risk of flooding in this area.

During the year the richest monthly leakage is achieved in the upper and middle basin between March to June, reaching the highest monthly flows in April at Teregova station and in May at Sadova, Caransebeş and Lugoj stations. The average flow during April at Teregova station is about $17 \%$ of the annual flow. The average flow in May is about $17 \%$ to Sadova, $15.6 \%$ at Caransebeş and $15.7 \%$ in Lugoj from the average annual of leakage. The highest values of the monthly average flow of April-May are not correlated with rainfall in these months, but are related to the water content of the snow layer from the Carpathian Basin. Hot air invasions from the Mediterranean induces the melting of snow, which cumulates to the amount of rainfall during these months.

Lowest monthly leakage occurs in autumn; in the months of September and October at Teregova (3.5\% of annual flow), in November at Sadova ( $4.5 \%$ of annual flow), in October in Caransebeş (4.8\% of annual flow) and in September in Lugoj (2.7\% of annual flow). It is linked to the production of small amounts of rainfall in the second half of the year, water consumption in biological processes during the vegetation period and high evaporation in the warm season of the year that reduces underground water reserves. 
The seasonal distribution of the liquid flow is determined by a combination of sources of supply and dominance, one of which is correlated with the deployment in the surface and elevation of the reception basin (Tab. 2, Fig. 2). Regarding the seasonal flow regime, the minimum value recorded in autumn both in the Carpathian Basin and in the Timiş Plain due to higher temperatures related to the establishment of an anticyclone regime in the Banat (Linc, 2002), is supplied mostly from underground consumption during the vegetation period and strong evaporation. The dynamics of air masses and Mediterranean cyclone activity, often acting in Banat, causes an accentuated instability during the cold season of the year. This explains the higher values of flow in winter, close to those of summer and in some years it exceeds even spring leakage.

The winter months contribute a proportion of 19 to $25 \%$ of the flow as a result of storing a large volume of water in solid form in the layer of snow and ice, the water supply being mainly accomplished from underground. Due to the increase of temperatures, melting snow, (especially in the lower basin) associated with rainfall from the months of March-April, leads as the equalizer; exceeding and even doubling the annual average values in this month, achieving approx. $40-45 \%$ of the annual flow (Tab. 2, Fig. 2). Highest monthly average flow occurs in the spring, in the months of April-May, when widespread melting of snow from the Carpathian Basin and rainfall are the main water supplies of the Timiş River and its tributaries. Thus, in the spring the richest leakage during the year ( $45 \%$ of the average annual flows) is done.

Table 2: Seasonal leakage in the Timiş Basin; data processed by Hydrological Yearbooks of the Institute of Hydrology and Water Management.

\begin{tabular}{|c|c|c|c|c|c|c|}
\hline \multirow[t]{2}{*}{ River/Station } & \multirow[t]{2}{*}{$\mathrm{F}\left(\mathrm{km}^{2}\right)$} & \multirow{2}{*}{$\begin{array}{r}\mathrm{H} \mathrm{m} \\
(\mathrm{m})\end{array}$} & \multicolumn{4}{|c|}{ Distribution of flow $\%$} \\
\hline & & & Winter & Spring & Summer & Autumn \\
\hline Timiş/Teregova & 142 & 871 & 19.0 & 44.3 & 23.8 & 12.7 \\
\hline Timiș/Sadova & 559 & 933 & 17.8 & 43.9 & 24.2 & 14.0 \\
\hline Timiş/Caransebeş & 1072 & 769 & 20.2 & 41.4 & 24.2 & 14.4 \\
\hline Timiş/Lugoj & 2706 & 665 & 25.6 & 42.3 & 22.1 & 10.0 \\
\hline
\end{tabular}

In the summer, the values of average flow decrease; this causes a flow of approx. 22$24 \%$ of the average annual flow. The rising temperatures combined with the sensible decrease of rainfall amounts and strong evaporation in the middle basin causes a drastic decrease of flow in the plain sector. During autumn, flow values are maintained at about $10-15 \%$ of the annual flow, being the lowest share from the annual values (with the highest weight in the Carpathian Basin - 15\% and the minimum weight - $10 \%$ in the plains).

Spatial representation and interpretation of data related to the multiannual average flow regime becomes very conclusive if the correlation between altitude basin and multiannual specific flow is made $\mathrm{q}\left(1 / \mathrm{s} \cdot \mathrm{km}^{2}\right)=\mathrm{f}(\mathrm{Hm})($ Tab. 3, Fig. 3). The figure shows a direct and strong correlation between specific average flow and average altitude of the basin. Considering the altitude as the main cause of differentiated distribution of leakage lies in synthesis of geographical conditions assembly that influence the flow: annual average amount of rainfall, the annual average of air temperature, the afforestation rate of the basin, the morphometric characteristics of landforms, and the hydro-physical features of geological substrata and soils etc. 


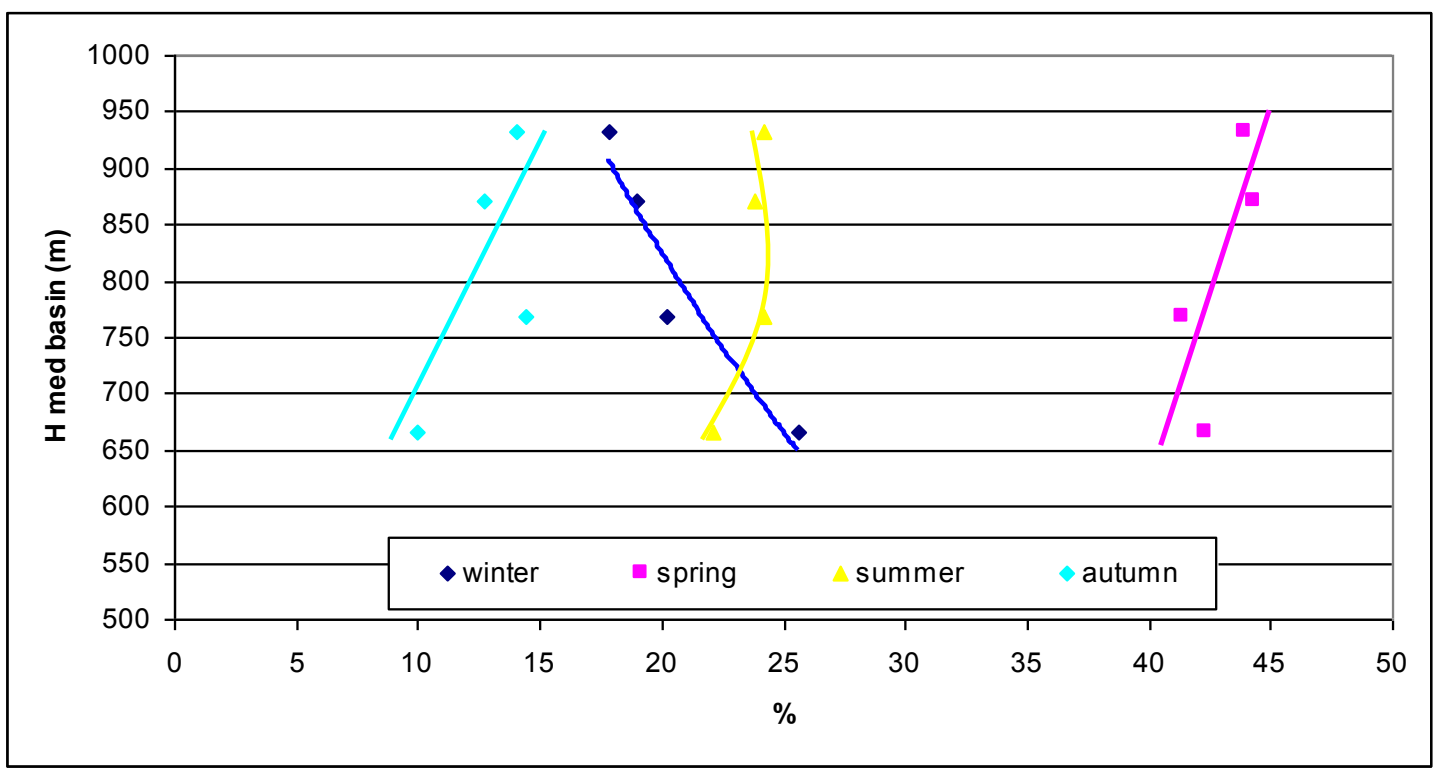

Figure 2: Seasonal average flow in the Timiş River basin.

Table 3: Hydrological parameters of Timiş River in some sections along the riverbed; source - INHGA, Q - average liquid flow; q - specific average flow.

\begin{tabular}{|l|c|c|c|c|c|c|c|}
\hline \multirow{2}{*}{ River/section } & \multirow{2}{*}{$\begin{array}{c}\mathrm{F} \\
\left(\mathrm{km}^{2}\right)\end{array}$} & $\begin{array}{c}\mathrm{H} \mathrm{m} \\
(\mathrm{m})\end{array}$ & $\begin{array}{c}\mathrm{Q} \\
\left(\mathrm{m}^{2} / \mathrm{s}\right)\end{array}$ & $\begin{array}{c}\mathrm{q} \\
(1 / \mathrm{s} . \mathrm{kmp})\end{array}$ & \multicolumn{3}{|c|}{$\begin{array}{c}\text { Monthly discharge }\left(\mathrm{m}^{3} / \mathrm{s}\right)- \\
\text { assured flow }\end{array}$} \\
\cline { 5 - 8 } & & & & & $80 \%$ & $90 \%$ & $95 \%$ \\
\hline Timiş/Teregovability levels
\end{tabular}

Non-periodic variation of flow recorded on the Timiş River from year to year is subordinated to weather and climate conditions and also to local conditions that contribute to the flows formation (underground intake, changes in land use, or modification of forest areas). Annual average flows were recorded unevenly in time and space. Linc (2002) calculated the annual average flow for the Caransebeş station, based on data for the period 1976-1996 that the annual average flows with different insurance. The results are presented in the table below (Tab. 4). 


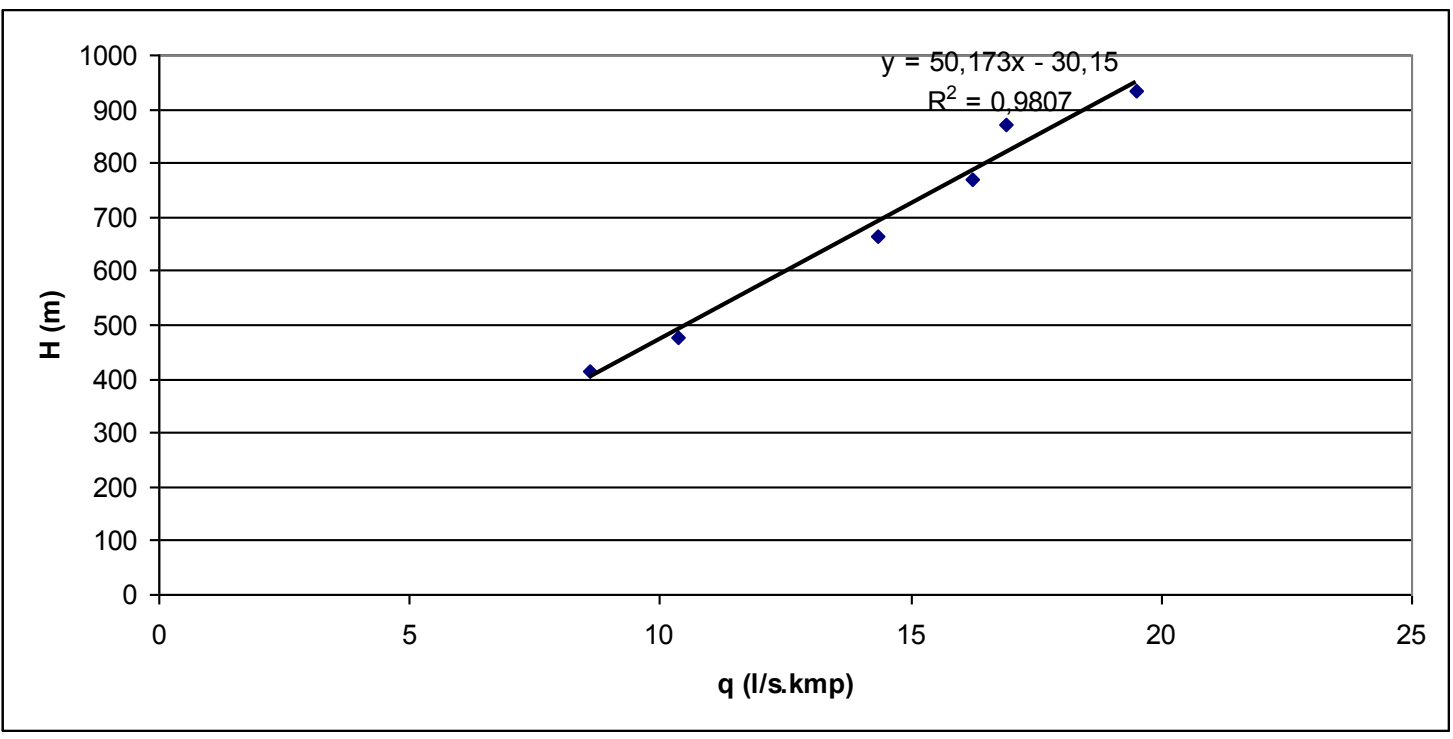

Figure 3: Specific average flow's correlation with mean elevation of the basin.

Table 4: Annual average flow rates with different insurances on the Timiş River; source: Linc, 2002, Cv - coefficient of variation of flow from average values, Cs - assymetry coefficient for characterization of insurance curve shape, Q - annual average flow $\left(\mathrm{m}^{2} / \mathrm{s}\right)$.

Caransebeş hydrological station $\mathrm{Cv}=0.28 ; \mathrm{Cs}=0.49 ; \mathrm{Q}=17.38$

\begin{tabular}{|l|c|c|c|c|c|c|c|}
\hline Insurance \% & 0.10 & 1 & 3 & 5 & 10 & 20 & 30 \\
\hline $\mathrm{Q}$ & 29.72 & 27.29 & 25.72 & 24.85 & 23.29 & 21.55 & 20.16 \\
\hline Insurance \% & 40 & 50 & 60 & 70 & 80 & 90 & 99 \\
\hline $\mathrm{Q}$ & 18.94 & 17.73 & 16.51 & 15.12 & 13.38 & 10.94 & 4.69 \\
\hline
\end{tabular}

\section{The maximum flow}

Maximum leakage raises the most important problems in the dynamic of riverbeds, aquatic ecosystems and wetlands. Flow phenomena, in most cases, are generating at largescale, hydrological risks manifested in the short term, but with long term repercussions (Ştef and Costea, 2006). These risks are associated with geomorphologic risk (torrent, breaking the banks, landslides, and floods), economic risk (destruction of crops, damage of economic objectives and communication networks, etc.) and even social risk (endangerment or even loss of human life). Maximum leakage requires constant monitoring, especially because of the Timiş River basin arrangment. Knowledge of levels and corresponding maximum flow is particularly important in the maintenance and operation of hydraulic and hydropower systems (Pop, 1996; Costea, 2006). 
Maximum leakage phenomenon is very complex, and is influenced by a series of factors which include: climatic factors (specially the amount and intensity of rainfall), basin shape and size, the slopes and riverbeds declivity, fragmentation, coverage and vegetation type, the physical and chemical properties of soil and geological substrata, the share of human intervention by deforestation, grazing, hydro exploitation etc., i.e. the ecologic state of the basin at the time of rainfall manifestation.

An important feature of flow in the upper basin of the Timiş River is the appearance with regularity of the annual flash floods, especially in the spring - summer season, from March to June (50\%). The highest values of maximum flow occur in May after snowmelt and overlap with the rainfall of this month (Badea et al., 1983). Moreover, about $17 \%$ of the annual maximum discharges have a mixed provenance. However, as a result of the warm Mediterranean air invasion, neither of the big winter waters is missing. These are resulting into sudden melting of the snow or rainfall and high flow from December to January $(44.0 \mathrm{mc} / \mathrm{s}$ $86 \mathrm{~m}^{2} / \mathrm{s}$ ).

Ujvari (1972) specified for the rivers of Banat that, compared to other regions, the maximum flow is higher for the same area of the basin due to the climatic regime, higher humidity and abundant rainfall. In the case of small basins size $\left(100-500 \mathrm{~km}^{2}\right)$, specific maximum leakage is about $120-1501 / \mathrm{s} \cdot \mathrm{km}^{2}$ in the Banat Plain, about $300-500 \mathrm{l} / \mathrm{s} \cdot \mathrm{km}^{2}$ in the Pogăniş Hills and about 1000 to $1600 \mathrm{l} / \mathrm{s} \cdot \mathrm{km}^{2}$ in the Carpathian Basin of Timiş. Peak flow values with different insurance are shown in table 5.

Table 5: Maximum flow on Timiş River with different insurances; source: INMH/INHGA, 1970 recalculated data and updated hydrological study.

\begin{tabular}{|l|c|c|c|c|}
\hline \multirow{2}{*}{ Hydrologicalstation } & \multicolumn{4}{|c|}{ Maximum flow $\left(\mathrm{m}^{2} / \mathrm{s}\right)$ - assured values } \\
\cline { 2 - 5 } & $1 \%$ & $2 \%$ & $5 \%$ & $10 \%$ \\
\hline Teregova & 230 & 176 & 125 & 90 \\
\hline Sadova & 475 & 385 & 345 & 280 \\
\hline Caransebeş & 700 & 475 & 320 & 210 \\
\hline Lugoj & 1225 & 1055 & 840 & 675 \\
\hline Şag & 1740 & 1500 & 1175 & 960 \\
\hline
\end{tabular}

Flash floods can occur in any month of the year. They have a higher rate of production between February to May and a lower frequency from August to September. Their production depends directly on the synoptic conditions and also on the morphometric characteristics of the river basin and riverbeds. Flash floods of pluvial provenance prevail, and in winter flash floods with nival provenance can be produced. The highest frequency has the monowave flash floods, but can also create the multiwaves flash floods. Table 6 shows the characteristic elements of individual flash floods produced at different hydrometric stations on the Timiş River between 1952-1999.

These phenomena have contributed to the formation of maximum flow to the Timiş River. The most representative flash floods occurred between January to March 1957, between $1978-1980\left(86.4 \mathrm{~m}^{2} / \mathrm{s}\right.$ in Caransebeş), in $1987\left(397 \mathrm{~m}^{2} / \mathrm{s}\right.$ - the highest value recorded in April to Caransebeş) in May 1981, from 6 to 10 June 1989, from 20 to 23 April 1998, from 20 to 26 February 1999, 6-7 April 2000, 23 to 26 April 2001, from 15 to 30 April 2005 (Tabs. 7 and 8). The last was by far the most important for the registered of peak flows and of water volumes in transit (http://www.inhga.ro/). 
Table 6: The characteristic elements of individual flash flood waves and layers drained volumes at the maximum flow with $1 \%$ insurance produced in the Timiş River; Source : INMH, update hydrological study 1970 - 1999; Ib - basin slope; Ir - riverbed slope; Tcr. - time of flow increase; Ttot. - total time of flashflood; W - volume of flasflood; $h$ - the thickness of drained water layer; $1 \%$ - insurance of flow.

\begin{tabular}{|c|c|c|c|c|c|c|c|c|c|c|}
\hline $\begin{array}{c}\text { Hydro } \\
\text { station }\end{array}$ & $\begin{array}{c}\mathrm{F} \\
\left(\mathrm{km}^{2}\right)\end{array}$ & $\begin{array}{c}\mathrm{Hm}(\mathrm{m}) \\
(\mathrm{L})\end{array}$ & $\begin{array}{c}\mathrm{Ib} \\
\% \mathrm{o}\end{array}$ & $\begin{array}{c}\mathrm{Ir} \\
\% \mathrm{o}\end{array}$ & $\begin{array}{c}\text { Tcr. } \\
\text { hours }\end{array}$ & $\begin{array}{c}\text { Ttot. } \\
\text { hours }\end{array}$ & $\mathrm{\Upsilon}$ & $\begin{array}{c}\mathrm{W}_{1 \%} \\
\mathrm{mil} . \mathrm{mc}\end{array}$ & $\begin{array}{c}\mathrm{h}_{1 \%} \\
\mathrm{~mm}\end{array}$ \\
\hline Teregova & 167 & 906 & 26.1 & 187 & 28.7 & 19 & 90 & 0.28 & 20.9 & 125 \\
\hline Caransebeș & 1072 & 769 & 60.0 & 286 & 15.6 & 33 & 135 & 0.30 & 102 & 95.2 \\
\hline Lugoj & 2706 & 665 & 116 & 258 & 8.8 & 45 & 179 & 0.26 & 209 & 77.4 \\
\hline Şag & 4493 & 468 & 194 & 175 & 5.4 & 54 & 210 & 0.27 & 356 & 79.2 \\
\hline
\end{tabular}

Table 7: Two significant flash foods on the Timiş River; source: INMH/INHGA.

\begin{tabular}{|c|c|c|c|c|c|}
\hline Date & Conditions & $\begin{array}{l}\text { Hydrographic } \\
\text { station }\end{array}$ & $\begin{array}{l}\text { Total } \\
\text { time } \\
\text { hours }\end{array}$ & $\begin{array}{c}\text { Maximum } \\
\text { flow } \\
\mathrm{m}^{2} / \mathrm{s}\end{array}$ & Observations \\
\hline \multirow[t]{2}{*}{$\begin{array}{l}\text { June } \\
1989\end{array}$} & \multirow{2}{*}{$\begin{array}{l}\text { In May the rainfall } \\
\text { exceeded about } 80 \\
1 / \mathrm{m}^{2} \text { the annual } \\
\text { average of the south- } \\
\text { west Carpathians } \\
\text { region; Between } 20 \\
\text { May and June } 6 \text { - } \\
\text { daily rainfall fell }\end{array}$} & Sadova & 80 & 97.4 & $\begin{array}{l}\text { Overcoming } \\
\text { attention quotas with } \\
\text { about } 60 \mathrm{~cm} . \text { Peak } \\
\text { quota of } 133 \mathrm{~cm} .\end{array}$ \\
\hline & & Caransebeş & 98 & 123 & $\begin{array}{l}\text { Overcoming } \\
\text { attention quotas with } \\
\text { about } 27 \mathrm{~cm} . \text { Peak } \\
\text { quota of } 147 \mathrm{~cm} .\end{array}$ \\
\hline \multirow{2}{*}{$\begin{array}{l}\text { April } \\
2005\end{array}$} & \multirow[b]{2}{*}{$\begin{array}{l}\text { Liquid precipitation } \\
\text { occurred during April } \\
14 \text { to } 28 \text {; The amount } \\
\text { of rainfall in } 15 \text { days } \\
\text { was } 201.2 \mathrm{~mm} \text {, } \\
\text { exceeding the annual } \\
\text { average of April } \\
(176.8 \mathrm{~mm}) \text {. }\end{array}$} & Lugoj & 72 & 1135 & \multirow[b]{2}{*}{$\begin{array}{l}\text { The highest flow } \\
\text { ever recorded on the } \\
\text { Timiş River, this led } \\
\text { to exceeding dam's } \\
\text { defense quotas and } \\
\text { to flooding } \\
\text { interfluves' area } \\
\text { between Timiş and } \\
\text { Bega rivers. }\end{array}$} \\
\hline & & Şag & & 1083 & \\
\hline
\end{tabular}

Table 8: Volumes and drained water layer on the Timiş River at flash flood from April 2005; source - INHGA 2005 quoted by Panţu, 2009; * = recorded values;** = reconstructed values by adding of volumes stored in permanent and non-permanent accumulations and of those lost by dykes breaking; Ws - drained volume; $\mathrm{Wt}=$ total volume; $\mathrm{h}_{\mathrm{p}+\mathrm{z}}=$ the thickness of the drained water layer on the basin surface, from rain and snowmelt.

\begin{tabular}{|l|c|c|c|c|}
\hline Secţiunea & $\mathrm{Q} \max \left(\mathrm{m}^{2} / \mathrm{s}\right)$ & $\mathrm{Ws}\left(10^{3} \mathrm{mc}\right)$ & $\mathrm{Wt}\left(10^{3} \mathrm{mc}\right)$ & $\mathrm{h}_{\mathrm{p}+\mathrm{Z}}(\mathrm{mm})$ \\
\hline Lugoj & 1135 & $350^{*}$ & $450^{*}$ & 166 \\
& & $372^{* *}$ & $472^{* *}$ & \\
\hline Şag & 1083 & $598^{*}$ & $796^{*}$ & 171 \\
& & $715^{* *}$ & $913^{* *}$ & \\
\hline Grăniceri & 920 & $296^{*}$ & $486^{* *}$ & 163 \\
& & $747^{* *}$ & $937^{* *}$ & \\
\hline
\end{tabular}


In the production condition of the above flow on the Timiş River in April 2005, the defense dikes which accompanies the river between Lugoj and the border, were exceeded (these dykes are classified as IVth class on the base of their importance) (http://www.rowater.ro/dabanat). Discharge areas were Lugoj - Coştei and Cebza - Grăniceri. Supplementation of the Timiş flow with debit transferred from the Bega River through the stack bypass of Topolovăţ (to avoid flooding of Timişoara) resulted in recording the largest flow that occurred on Timiş in the Banat Plain. The river overflows the embankment and has produced some breaches downstream to Crai Nou which led to flooding of the Timiş - Bega interfluve and to the calamity of the localities of Foeni, Cruceni, Giulvăz, Rudna, Crai Nou, Ivanda, Rudna, Peciu Nou, Diniaş, Sânmartinu Sârbesc, Gad, Uivar, Otelec and Ionel (Panţu, 2009).

\section{The minimum flow}

Minimum leakage is recorded over the entire basin of Timiş, but mainly characterizes the upper basin in the Caransebeş Depression and the lower basin in the Timiş Plains, where the flow is significantly reduced. This hydrological indicator is directly dependent on the groundwater supply, on the depletion degree of the underground water resources and on interception of these resources by riverbeds.

Minimum leakage occurs in two distinct periods of the year and presents differences along the river. Minimum flows recorded in the winter are characteristic to the upper basin and the summer - autumn minimum flows are characteristic to the depression and plain area. Minimum leakage between December to March is due to the winter meteorological phenomena such as: frost, snow falls, and average daily temperatures below $0^{\circ} \mathrm{C}$, water storage in the snow layer and due to emergence and evolution of winter phenomena on rivers, especially ice bridge. The minimum, for the interval August-September coincides with the vegetation season, where the maximum water consumption is recorded; the evaporation increases due to the high temperature and the rainfall is also the lowest.

Due to the contribution of the permanent springs and almost uniformly distributed rainfall all year round in the Carpathian Basin of Timiş, the leakage is not totally reduced. There are situations where flows were greatly reduced; in the droughty years the flow reached the lower limit, about $85 \%$ probability of occurrence. Also, the minimum flow of the Carpathian Basin of Timiş is substantially influenced by reservoirs; downstream of the Trei Ape Dam the flow is reduced significantly in lengths of 500-1,000 m, being ensured only the flow of servitude.

The middle basin corresponding to the Banat Plain is facing a minimum leakage more pronounced in summer and autumn, when the Timiş River and its tributaries supply exclusively from groundwater sources and the high temperatures favour a large loss by evaporation. Added to these factors are the interception and the water consumption by spontaneous vegetation and crops. Moreover, the minimum flow values are significantly altered in the plain of water uses in agriculture and retentions along the Timiş River or the tributaries.

Rivers flowing is a common phenomenon in the Banat Plain, and is not only because of the climate condition like pluvial and thermal variability. Other causes are the geological substrate, high permeability and its composition of gravel and sands deposits (Geological Map, 1968) which favours rainwater infiltration under the riverbeds and very small slope that impedes the water drainage to the Timiş riverbed and tributaries. Table 9 cumulates the minimum flow data for different insurance on the Timiş River. 
Table 9: Characteristic data regarding the minimum flow on the Timiş River (INHGA).

\begin{tabular}{|c|c|c|c|c|c|c|}
\hline \multirow[t]{2}{*}{$\begin{array}{l}\text { Hydrological } \\
\text { section }\end{array}$} & \multicolumn{3}{|c|}{$\begin{array}{c}\text { Minimum flow } \\
\text { with different insurance } \\
\mathrm{q}\left(1 / \mathrm{s} \cdot \mathrm{km}^{2}\right) \mathrm{Q}\left(\mathrm{m}^{2} / \mathrm{s}\right)\end{array}$} & \multicolumn{3}{|c|}{$\begin{array}{l}\text { Minimum monthly average flow } \\
\text { VI - VIII by various insurance } \\
\text { companies } \mathrm{q}\left(\mathrm{l} / \mathrm{s} \cdot \mathrm{km}^{2}\right) \mathrm{Q}\left(\mathrm{m}^{2} / \mathrm{s}\right)\end{array}$} \\
\hline & $80 \%$ & $90 \%$ & $95 \%$ & $80 \%$ & $90 \%$ & $95 \%$ \\
\hline \multirow{2}{*}{ Teregova } & 3.34 & 2.94 & 2.40 & 5.07 & 4.20 & 3.70 \\
\hline & 0.56 & 0.49 & 0.40 & 0.85 & 0.70 & 0.62 \\
\hline \multirow{2}{*}{ Lugoj } & 1.85 & 1.66 & 1.47 & 2.84 & 2.10 & 1.66 \\
\hline & 5.00 & 4.50 & 4.00 & 7.70 & 5.70 & 4.50 \\
\hline
\end{tabular}

\section{CONCLUSIONS}

Considering that flow interacts with all environmental components, knowledge of its characteristic values has a great practical importance for determining water reserves from the Timiş River and the tributaries in order to satisfy the utilities, ensure ecological flow and avoid the hydrological risk. For the analysis of morphohydrographic and ecological systems along the Timiş and to preserve the ecological balance, it is necessary to know the hydrological regime of the river; especially knowing the degree of maximum and minimum flow rates at different times of the year and different durations. The Timiş River's hydrological regime has a great variability and variation in time and space. It depends on the altitude, by the climate conditions and by the peculiarities of geological substrate. The natural and anthropogenic conditions are different, depending on relief units (mountains, hills, plains) drained by Timiş.

Altitudinal variation of the flow regime for the upper basin is specific to the Western Carpathian type, with spring high water occurring early and lasting for 1-2 months, with high Carpathian hydrograph for the upper basin (the highest leakage is recorded in winter, spring, and then in autumn, with a mixed supply). Summer can record longer periods of dryness and even drought. Autumn floods have a frequency of $30-45 \%$ in the Carpathian sector of the basin and winter floods are above $30 \%$, and can have catastrophic effects.

The middle basin has a west peripheral-Carpathian drainage regime, with a high percentage of winter leakage (35-40\%) due to the accentuated instability and action of barometric centres and Mediterranean cyclones. Warm and moist air masses, originating from the Mediterranean, produce sudden melting of snow in the winter not only in the western periphery of Carpathian (Banatului Plain) area but also in the upper basin (Banatului and Godeanu - Ţarcu mountains), which causes winter nival-pluvial and pluvial floods. The frequencies of floods in warm winters reach around $60-70 \%$. The months of May and June are also characterized by a high leakage with numerous floods, and during summer and autumn the small waters are installed. The interval from November to December is also noted by leakage increase, with pluvial floods at a frequency of $50-60 \%$.

Due to numerous arrangements in the Timiş Basin, the natural flow regime is altered by the storing of water in lakes and by the artificial flow transfer between Timiş Basin and Bega Basin and vice versa. Major influences on the flow regime are? the consumers, especially urban settlements and agriculture. A real analysis of the hydrological features must be based on the updating and restoring of natural flow. This operation needs a great effort to update the hydrological data base with the data registered in the last years, to quantify the volume of drained water in the managed regime and to assess the volume which would be taken by consumers. This requires a good management at INHGA, a good collaboration with another institution and also a better knowledge of field reality. 


\section{ACKNOWLEDGMENTS}

This work is a part of the scientific study of the quality of the Timiş River water, "Study of the quality of Timiş water and registry of polluters source to border" (IV.1.2), a Phare CBS contract, no. 411 - 90964/30.12.2010/07 of "Lucian Blaga" University, Faculty of Sciences, financed by the European Community. The author is grateful to Ecotur Sibiu NGO for the publishing of this paper. Also, the author thanks the reviewers for suggestions and to all colleagues involved in the research, especially to Mr. Bănăduc D. for the support in riverbed measurement in the field campaign.

\section{REFERENCES}

1. Costea M., 2006 - Riscul la inundaţii. Impactul în peisaj, în Hidrologie aplicată, Ştef V. and Costea M., (eds.), Edit. Universității "Lucian Blaga" din Sibiu, 205-240. (in Romanian)

2. Linc R., 2002 - Culoarul Timiş-Cerna, Edit. Universităţii din Oradea. (in Romanian)

3. Panţu H., 2009 - Modernizarea sistemului hidrotehnic Timiş - Bega, Edit. Politehnica, Timişoara, 241. (in Romanian)

4. Pop G., 1996 - România. Geografie hidroenergetică, Edit. Presa Universitară Clujeană, ClujNapoca, 233. (in Romanian)

5. Ștef V. and Costea M., 2006 - Hidrologie aplicată, Edit. Universității "Lucian Blaga" din Sibiu, 297. (in Romanian)

6. Diaconu C., 1971 - Râurile României. Monografie hidrologică, Edit. INMH, București, 494. (in Romanian)

7. Badea L., Gâştescu P. and Velcea V., 1983 - Geografia României. Geografie fizică, Edit. Academiei, București, 652. (in Romanian)

8. Oancea D. and Velcea V. (coord.), 1987 - Geografia României, III, Carpații şi Depresiunea Transilvaniei, Edit. Academiei Române, București, 647. (in Romanian)

9. Badea L. and Bugă D. (coord.), 1992 - Geografia României IV, Regiunile pericarpatice, Edit. Academiei Române, București, 580. (in Romanian)

10. ***, 1968 - Harta geologică a României. Foile Jimbolia, Timişoara, Deva, Scara 1:200000, Institutul Geologic al României.

11. http://www.rowater.ro/dabanat/default.aspx

12. http://www.rowater.ro/INHGA/default.aspx 